\title{
STUDY OF HORMONAL PROFILE IN FEMALE MELASMA PATIENTS IN A TERTIARY CARE HOSPITAL
}

\author{
Kiran Kumre1, Krishnendra Varma², Harsh Sharma³, Ujjwal Singh ${ }^{4}$ \\ ${ }_{13}^{\text {rd }}$ Year Post Graduate, Department of Dermatology, R. D. Gardi Medical College. \\ ${ }^{2}$ Professor \& HOD, Department of Dermatology, R. D. Gardi Medical College. \\ ${ }^{3}$ Assistant Professor, Department of Dermatology, R. D. Gardi Medical College. \\ ${ }_{4}^{4}$ Associate Professor, Department of Dermatology, R. D. Gardi Medical College.
}

ABSTRACT

\section{BACKGROUND}

Melasma is a chronic skin disorder that results in symmetrical, blotchy, brownish facial pigmentation.

AIM

To study the hormonal profile (T3, T4, TSH, Oestrogen, Progesterone, Prolactin) in female melasma patients.

\section{OBJECTIVES}

To study the hormonal profile (Sr. oestrogen, progesterone, prolactin, T3, T4 and TSH) and hormonal imbalance in female melasma patients attending Dermatology OPD of CRGH within 1 year by correlating with the normal levels.

\section{MATERIALS AND METHODS}

Sixty-six female patients suffering from melasma between the ages of 15-45 years were enrolled in the study. Patients were investigated for various hormone levels, i.e. T3, T4, TSH, Oestrogen, Progesterone, Prolactin at any time of their menstrual cycle and their values estimated according to Follicular (FP) and Luteal Phase (LP) values.

\section{RESULTS}

Amongst the sixty-six patients only 18 (27.3\%) had normal values for oestrogen, while the remaining 48 patients $(72.7 \%)$ had deranged values (Mostly increased). Out of 66 patients, progesterone level was normal in 28 (42.4\%) and deranged in 38 (57.6\%). Prolactin level was found normal in $59(89.4 \%)$ and deranged in $7(10.6 \%)$ of the patients. T3 level was found to be normal in 49 (74.2\%), increased in $9(13.6 \%)$ and decreased in $8(12.1 \%)$ of the patients. T4 was found normal in 51 (77.3\%), increased in 8 $(12.1 \%)$ and decreased in $7(10.6 \%)$ of the patients. TSH level was found normal in $43(65.2 \%)$, increased in $18(27.3 \%)$ and decreased in $5(7.6 \%)$ of the patients.

\section{CONCLUSION}

It was concluded raised oestrogen and progesterone levels contribute towards the development of melasma. Hypothyroidism is found to be associated with melasma in many cases.

\section{KEYWORDS}

Melasma, Hypothyroidism, Oestrogen, Progesterone, Melanin Stimulating Hormone.

HOW TO CITE THIS ARTICLE: Kumre K, Varma K, Sharma H, et al. Study of hormonal profile in female melasma patients in a tertiary care hospital. J. Evolution Med. Dent. Sci. 2016;5(31):1663-1666, DOI: 10.14260/jemds/2016/392

\section{INTRODUCTION}

Melasma is a common skin problem that is also known as 'chloasma.' It causes brown patches on the face; most commonly appearing on the cheeks, bridge of the nose, forehead, chin and above the upper lip. It can appear on other parts of the body that get more exposed to sunlight. Hormonal changes along with sun exposure are the most common triggers for melasma. Although melasma may affect both men and women, the majority of those affected are women. Elevated levels of oestrogen and progesterone (As occurring in pregnancy) are important. Melasma also develops with oestrogen and progesterone-containing pills.[1]

However, progesterone may be more important, as melasma develops in postmenopausal women who are given

Financial or Other, Competing Interest: None.

Submission 13-01-2016, Peer Review 23-03-2016,

Acceptance 28-03-2016, Published 18-04-2016.

Corresponding Author:

Dr. Kiran Kumre,

Room No. 404, RMO Hostel,

R. D. Gardi Medical College,

Surasa, Ujjain-456006.

E-mail: jsmtlmb7@gmail.com

DOI: $10.14260 /$ jemds/2016/392 progesterone and not when given oestrogen supplementation. Oestrogen probably stimulates melanogenesis through oestrogen receptors present on melanocytes. ${ }^{[2]}$ Other hormones may also be important. Melasma is several times commoner in patients with thyroid disease and Melanin Stimulating Hormone (MSH) may be important as melasma frequently begins as well as worsens during pregnancy as also after profound emotional stress.

\section{MATERIAL AND METHODS}

The present study was a prospective observational study in which female patients attending Dermatology OPD in CRGH, Ujjain, Madhya Pradesh with a diagnosis of melasma were recruited for the study. A total of 66 cases of clinically diagnosed female melasma patients of reproductive age group (15-45 yrs.) constituted the subject material for present study. These patients belonged to Ujjain and its adjoining districts. Prior approval for the study and the protocol was obtained from the ethical committee.

Post inflammatory hyperpigmentation, other pigmentary disorders with epidermal dermal pigmentation (Nevus of Ota, Nevus of Ito, Mongolian spots) were excluded. Informed written consent was taken from cases for the 
inclusion in the study. Detailed history and clinical examination findings of Melasma cases was done. Routine investigations and hormonal profile, i.e. Sr. oestrogen, progesterone, prolactin, T3, T4, TSH was sent to the biochemistry laboratory of the CRGH. Sample was drawn at any time of the menstrual cycle. Estradiol and progesterone were estimated by Radioimmunoassay (RIA). The data were collected and transferred to SPSS version 16 and analysed accordingly. Conclusion was established on the grounds of all findings.

\section{Distribution of Number of Cases According to Oestrogen} Level

\begin{tabular}{|c|c|c|c|c|}
\hline \multirow{2}{*}{$\begin{array}{c}\text { Sl. } \\
\text { No. }\end{array}$} & $\begin{array}{c}\text { Normal } \\
\text { oestrogen } \\
\text { (pg/mL) }\end{array}$ & $\begin{array}{c}\text { Oestrogen } \\
\text { Level }\end{array}$ & $\begin{array}{c}\text { No. of } \\
\text { Cases }\end{array}$ & Percentage \\
\hline 1 & $26.1161(\mathrm{FP})$ & Normal & 18 & 27.3 \\
\cline { 3 - 5 } & $32.7-201(\mathrm{LP})$ & Abnormal & 48 & 72.3 \\
\hline & & Total & $\mathbf{6 6}$ & $\mathbf{1 0 0}$ \\
\hline
\end{tabular}

Oestrogen level of $18(27.3 \%)$ patients was found to be normal, while that of $48(72.7 \%)$ was found to be deranged.

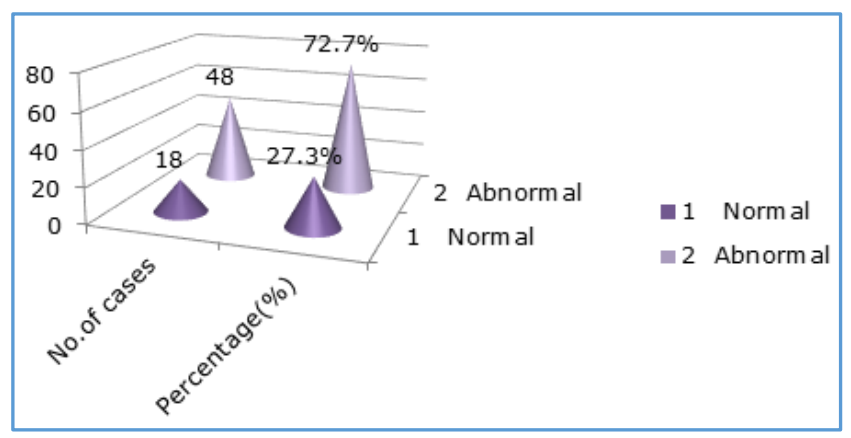

Distribution of Number of Cases According to Progesterone Level

Out of 66 patients, progesterone level was normal in 28 $(42.4 \%)$ patients and deranged in $38(57.6 \%)$.

\begin{tabular}{|c|c|c|c|c|}
\hline \multirow{2}{*}{$\begin{array}{c}\text { Sl. } \\
\text { No. }\end{array}$} & $\begin{array}{c}\text { Normal } \\
\text { Progesterone } \\
\mathbf{( n g / m L )}\end{array}$ & $\begin{array}{c}\text { Progesterone } \\
\text { Level }\end{array}$ & $\begin{array}{c}\text { No. of } \\
\text { Cases }\end{array}$ & $\mathbf{\%}$ \\
\cline { 1 - 3 } 1 & $0.14-2.03(\mathrm{FP})$ & Normal & 28 & 42.4 \\
\cline { 1 - 3 } 2 & $5.22-22.7(\mathrm{LP})$ & Abnormal & 38 & 57.6 \\
\hline & & Total & $\mathbf{6 6}$ & $\mathbf{1 0 0}$ \\
\hline
\end{tabular}

Distribution of Number of Cases According to Prolactin Level

\begin{tabular}{|c|c|c|c|c|}
\hline $\begin{array}{c}\text { Sl. } \\
\text { No. }\end{array}$ & $\begin{array}{c}\text { Normal Prolactin } \\
\text { Values }(\mathbf{p g} / \mathbf{m L})\end{array}$ & $\begin{array}{c}\text { Prolactin } \\
\text { Level }\end{array}$ & $\begin{array}{c}\text { No. of } \\
\text { Cases }\end{array}$ & (\%) \\
\hline 1. & $3-18.6 \mathrm{ng} / \mathrm{mL}$ & Normal & 59 & 89.4 \\
\cline { 4 - 5 } & & Abnormal & 7 & 10.6 \\
\hline 2. & & Total & $\mathbf{6 6}$ & $\mathbf{1 0 0 . 0}$ \\
\hline
\end{tabular}

Prolactin level was found normal in $59(89.4 \%)$ and deranged in 7 (10.6\%) of the patients.

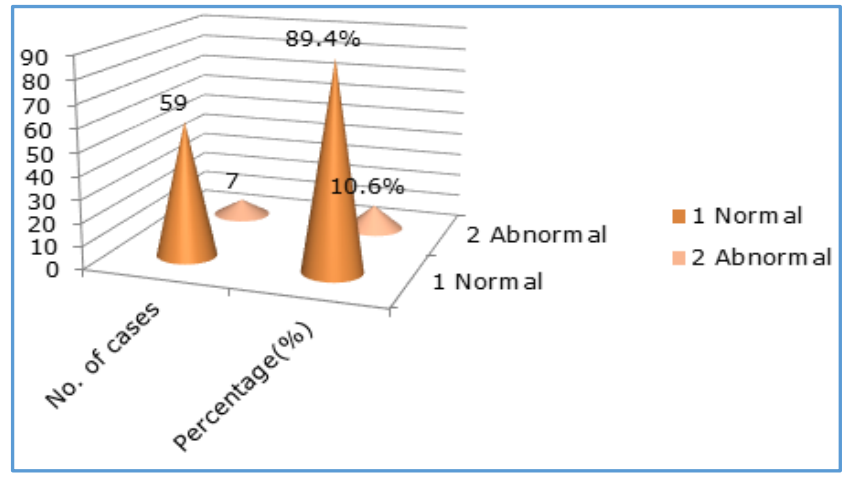

Distribution of Number of Cases According to T3 level

\begin{tabular}{|c|c|c|c|c|}
\hline $\begin{array}{c}\text { Sl. } \\
\text { No. }\end{array}$ & $\begin{array}{c}\text { Normal T3 } \\
\text { Values }\end{array}$ & T3 Level & $\begin{array}{c}\text { No. of } \\
\text { Cases }\end{array}$ & (\%) \\
\hline 1. & \multirow{2}{*}{$2.77-5.27$} & Normal & 49 & 74.2 \\
\cline { 4 - 5 } & $\mathrm{pg} / \mathrm{mL}$ & Increased & 9 & 13.6 \\
\cline { 4 - 5 } & & Decreased & 8 & 12.1 \\
\hline 3. & & Total & $\mathbf{6 6}$ & $\mathbf{1 0 0 . 0}$ \\
\hline
\end{tabular}

Thyroid profile was done of all the melasma patients enrolled for the study and T3 level was found to be normal in $49(74.2 \%)$, increased in $9(13.6 \%)$ and decreased in 8 $(12.1 \%)$ of the patients.

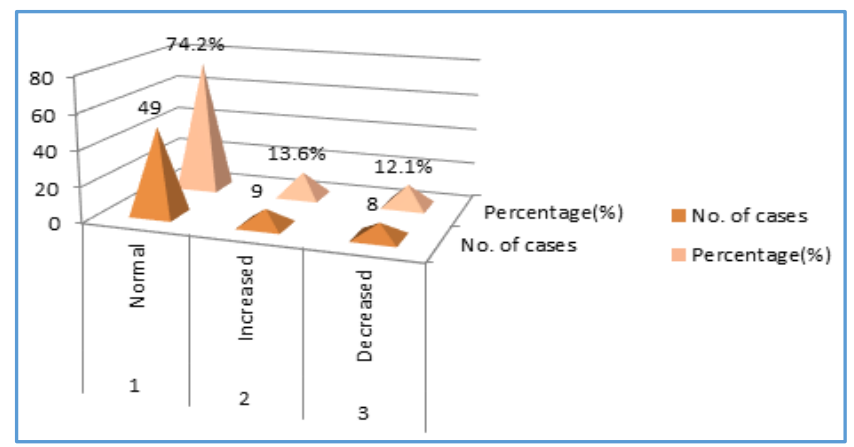

Distribution of Number of Cases According to T4 Level

\begin{tabular}{|c|c|c|c|c|}
\hline $\begin{array}{c}\text { Sl. } \\
\text { No. }\end{array}$ & $\begin{array}{c}\text { Normal T4 } \\
\text { Values }\end{array}$ & $\begin{array}{c}\text { T4 } \\
\text { Level }\end{array}$ & $\begin{array}{c}\text { No. of } \\
\text { Cases }\end{array}$ & (\%) \\
\hline 1. & \multirow{2}{*}{$5.53-11.1$} & Normal & 51 & 77.3 \\
\cline { 4 - 5 } & $\mu \mathrm{g} / \mathrm{dL}$ & Increased & 8 & 12.1 \\
\cline { 3 - 5 } 2. & Decreased & 7 & 10.6 \\
\hline 3. & & Total & $\mathbf{6 6}$ & $\mathbf{1 0 0 . 0}$ \\
\hline & & \multicolumn{2}{|c}{} \\
\hline
\end{tabular}

T4 was found normal in 51 (77.3\%), increased in 8 $(12.1 \%)$ and decreased in $7(10.6 \%)$ of the patients.

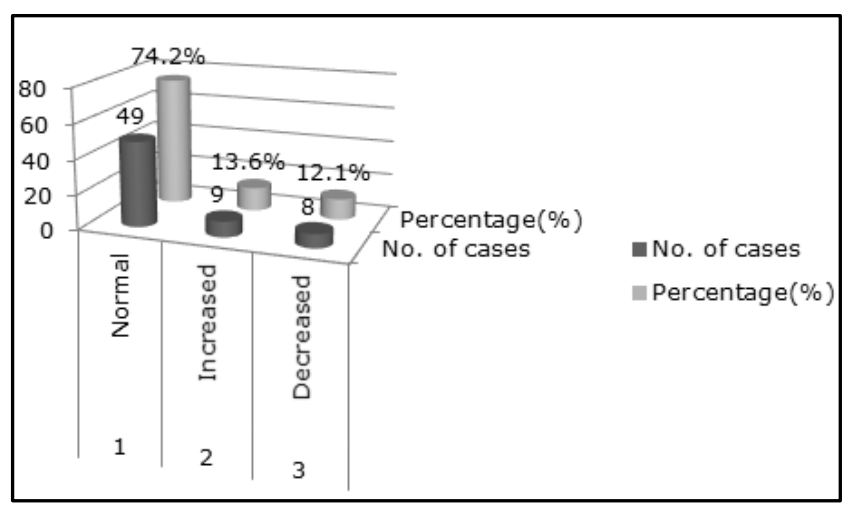


Distribution of Number of Cases According to TSH Level

\begin{tabular}{|c|c|c|c|c|}
\hline $\begin{array}{c}\text { Sl. } \\
\text { No. }\end{array}$ & $\begin{array}{c}\text { Normal TSH } \\
\text { Values }\end{array}$ & $\begin{array}{c}\text { TSH } \\
\text { Level }\end{array}$ & $\begin{array}{c}\text { No. of } \\
\text { Cases }\end{array}$ & (\%) \\
\hline 1. & \multirow{2}{*}{$0.456-4.68$} & Normal & 43 & 65.2 \\
\cline { 4 - 5 } & mIL/L & Increased & 18 & 27.3 \\
\cline { 4 - 5 } 2. & Decreased & 5 & 7.6 \\
\hline 3. & & Total & $\mathbf{6 6}$ & $\mathbf{1 0 0 . 0}$ \\
\hline & & &
\end{tabular}

TSH level was found normal in $43(65.2 \%)$, increased in $18(27.3 \%)$ and decreased in $5(7.6 \%)$ of the patients.

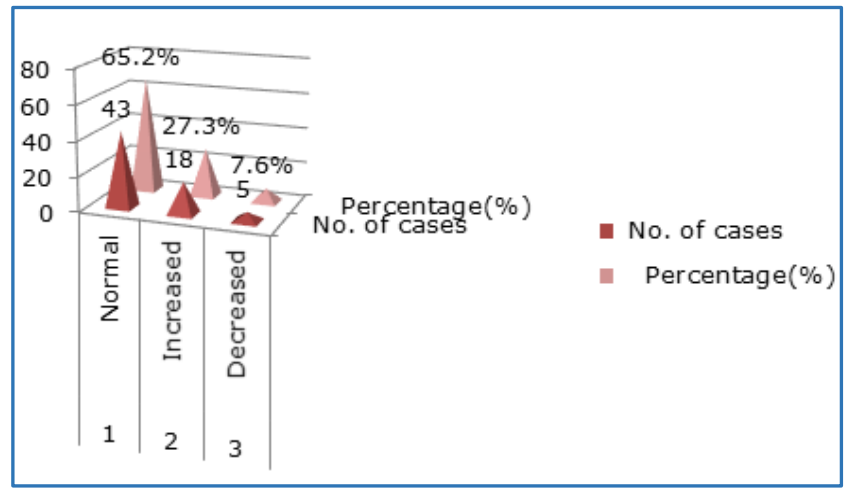

\section{DISCUSSION}

The exact cause of melasma is uncertain, but a direct relationship with female hormonal activity appears to be significant as it commonly occurs in pregnancy and with the use of oral contraceptive pills. ${ }^{[3]}$ Melasma is thought to be due to the stimulation of melanocytes by the female sex hormones oestrogen and progesterone to produce more melanin pigments when the skin is exposed to sun. Many cases appear to be related to excess oestrogen, either produced endogenously during pregnancy or delivered exogenously through the use of oral contraceptive pills and hormone replacement therapy. However, the mechanism of this interaction has not been elucidated. Vitro studies.[4,5] have shown that cultured human melanocytes express oestrogen receptors and estradiol increases the levels of tyrosinase, tyrosinase-related-protein 1 and 2, the enzymes involved in human eumelanogenesis within normal human melanocytes. Although, oestrogen has been hypothesized to be central in the pathogenesis of melasma, there had been few studies to support this view.

It is known that melanogenesis is mediated, at least in part by the binding of melanocyte stimulating hormone to the human melanocortin receptor 1 (MCR1) in normal human melanocytes, while estradiol increases MCR1, mRNA levels and tyrosinase levels, although the mechanism of these responses has not been established.[5,6] In our study, all the patients were married. Sixty six females with an age range of $15-45$ years were enrolled; $33(50.0 \%)$ belonged to the age group 26-35 years, 17 (25.8\%) were of 15-25 years and 16 $(24.25 \%)$ in the age range of $36-45$ years, while the mean age of all the patients was 30.5 years. In our study out of 66 patients oestrogen level of $18(27.3 \%)$ patients was found to be normal, while that of $48(72.7 \%)$ was found to be deranged with either an increase or decrease, mostly increased in the estradiol levels.

This is similar to the study of Khalid Mahmood et al.[7] in which $89.1 \%$ showed deranged values of oestrogen (Mostly increased), while Jee et al.[8] reported a dose-dependent proliferation of melanocytes in culture after $17 \beta$-estradiol addition, despite a decrease of tyrosinase activity and melanin content, Hassan I et al. ${ }^{[9]}$ observed higher levels of $E_{2-17} \beta$ on 5, 7,9 day in the study group indicating a possible role of high $\mathrm{E}_{2}$ $17 \beta$ in the maintenance of melasma, and Kim NH et al.[10] showed down-regulation of $\mathrm{H} 19$ and the development of melasma with a sufficient dose of oestrogen treatment.

\section{Progesterone}

Other hormones involved in a woman's menstrual cycle and pregnancy including progesterone and $\alpha-\mathrm{MSH}$, can also stimulate pigmentation. Melasma skin has also been shown to be more progesterone-responsive than normal skin. Oral contraceptives containing progestin only and not oestrogen also cause melasma. In our study out of 66 patients, progesterone level was normal in $28(42.4 \%)$ patients and deranged in 38 (57.6\%). This is similar to the study of Khalid Mahmood et al.[7] in which the values of progesterone were normal in $62(44.9 \%)$ patients and deranged in 76 (55.1\%) patients, while Sato et al.[11] reported increased levels of progesterone and Maeda et al.[12] showed enlarged and dendritic human melanocytes in culture after a 2-day incubation with the ovarian (Estradiol, estriol and progesterone) hormones by increasing TRP-1.

\section{Prolactin}

As melasma is found to be aggravated during pregnancy and oestrogen and progesterone play an important role in causation of melasma, role of prolactin hormone which is also increased in pregnancy has also been studied here. In our study, prolactin level was found normal in 59 (89.4\%) and deranged in $7(10.6 \%)$ of the patients. This is higher than the study of Khalid Mahmood et al.[7] in which prolactin levels were normal in 134 (97.1\%) patients and deranged in 4 (2.9\%), while Hassan I et al.[9] revealed decreased and Pérez et al.[13] found normal prolactin levels on $9^{\text {th }}$ day of cycle.

\section{T3, T4, TSH}

Thyroid hormones also play an important role in monitoring the health and appearance of the skin as people with melasma are four times as likely to have a thyroid abnormality than those with normal skin pigmentation. Thus, thyroid dysfunction causes skin disorders. In our study, T3 level was found to be normal in $49(74.2 \%)$, increased in $9(13.6 \%)$ and decreased in $8(12.1 \%)$ of the patients. T4 was found normal in $51(77.3 \%)$, increased in $8(12.1 \%)$ and decreased in 7 $(10.6 \%)$ of the patients. TSH level was found normal in 43 (65.2\%), increased in $18(27.3 \%)$ and decreased in 5 (7.6\%) of the patients. This is somewhat similar to the study of Lutfi et al.[14] and Alka Dogra et al.[15] who showed 58.3\% and 23\% associated with thyroid diseases, while Rezwan Talaee et al.[16] showed T3, T4 levels normal, TSH higher and Yazdanfar et al.[17] showed significantly higher levels of T3 and Anti-TPO in melasma cases.

\section{CONCLUSION}

It was concluded that raised oestrogen and progesterone levels contribute towards the development of melasma. Hypothyroidism is found to be associated with melasma in many cases. There is no strong evidence of a relationship between melasma and thyroid disorders. Both melasma and thyroid diseases are very common in young women, hence this 
could erroneously lead to suggestions of a relationship between the two conditions when one does not really exist.

\section{REFERENCES}

1. Grimes PE, Yamada N, Bhawan J. Light microscopic, immunohistochemical and ultrastructural alteration in patients with melasma. Amer J Dermatopathol 2005;27(2):96-101.

2. Bandyopadhyay D. Topical treatment of melasma. Indian J Dermatol 2009;54(4):303-9.

3. Grimes PE. Melasma: etiologic and therapeutic considerations. Arch Dermatol 1995;131(12):1453-7.

4. Im S, Eun-So L, Kim W, et al. Donor specific response of oestrogen and progesterone on cultured human melanocytes. J Korean Med Sci 2002;17(1):58-64.

5. Kippenherger S, Loitsch S, Solano F, et al. Quantification of tyrosinase, TRP-1 and TRP-2 transcripts in human melanocytes by reverse transcriptase-competitive multiplex PCR--regulation by steroid hormones. J Invest Dermatol 1998;110(4):364-7.

6. Suzuki I, Cone RD, Im S, et al. Binding of melanotropic hormones to the melanocortin receptor MC1R on human melanocytes stimulates proliferation and melanogenesis. Endocrinology 1996;137(5):1627-33.

7. Khalid Mahmood, Muhammad Nadeem, Shahbaz Aman, et al. Role of estrogen, progesterone and prolactin in the etiopathogenesis of melasma in females. Journal of Pakistan Association of Dermatologists 2011;21(4): 2417.

8. Jee SH, Lee SY, Chiu HC, et al. Effects of oestrogen and oestrogen receptor in normal human melanocytes. Biochem Biophys Res Commun 1994;199(3):1407-12.
9. Hassan I, Kaur I, Sialy R, et al. Hormonal milieu in the maintenance of melasma in fertile women. J Dermatol 1998;25(8):510-2.

10. Kim $\mathrm{NH}$, Lee $\mathrm{CH}$, Lee $\mathrm{AY}$. H19 RNA downregulation stimulated melanogenesis in melasma. Pigment Cell Melanoma Res 2010;23(1):84-92.

11. Sato N. Endocrine environment in adult females with chloasma. Nihon Hifuka Gakkai Zasshi 1987;97(8):93743.

12. Maeda K, Naganuma M, Fukuda M, et al. Effect of pituitary and ovarian hormones on human melanocytes in vitro. Pigment Cell Res 1996;9(4):204-12.

13. Pérez M, Sánchez JL, Aguiló F. Endocrinologic profile of patients with idiopathic melasma. J Invest Dermatol 1983;81(6):543-5.

14. Lutfi RJ, Fridmanis M, Misiunas AL, et al. Association of melasma with thyroid autoimmunity and other thyroidal abnormalities and their relationship to the origin of the melasma. J Clin Endocrinal Metab 1985;61(1):28-31.

15. Dogra A, Dua A, Singh P. Thyroid and skin. Indian J Dermatol 2006;51(2):96-9.

16. Rezvan Talaee, Iman Ghafarpasand, Hamidreza Masror. The relationship between melasma and disturbances in the serum level of thyroid hormones and indices. Medicine Journal 2015;2(2):19-23.

17. Yazdanfar A, Hashemi B. Association of melasma with thyroid autoimmunity: a case-control study. Iranian Journal Of Dermatology 2010;13(2):51-3. 